\title{
Nesne İlişkileri Kuramı Çerçevesinden Borderline (Sınır) Kişilik Örgütlenmesine Bakış: Vaka Örneği ile Psikoterapi Sürecinin Yorumlanması
}

\author{
Hande Gündoğan* \\ Orta Doğu Teknik Üniversitesi
}

\begin{abstract}
Özet
Borderline (sınır) kişilik örgütlenmesi, kimlik dağılması (tutarsız ve çelişkili benlik ve öteki algısı), ilkel savunmaların kullanılması (çoğunlukla bölme [splitting] ve yansıtmalı özdeşim [projective identification]) ve gerçeği değerlendirme yetisinde e ksiklikler ile karakterize olan güçsüz benliğin yer aldığı kişilik örgütlenmesi olarak tanımlanmaktadır. 32 yaşında bekar ve çalışan bir kadın olan Beril M.'nin başvuru nedenleri ve terapi sürecinde gündem olan şikayetleri dayanak alınarak tanımlama doğrultusunda borderline kişilik örgütlenmesine sahip olduğu düşünülmektedir. Borderline kişilik örgütlenmesini formüle eden temel teorilerden bir tanesi nesne ilişkileri kuramıdır. Nesne ilişkileri kuramı, Freud'un psikanalitik kuramının devamı olarak görülmektedir. Nesne ilişkileri teorisi, bebeğin 3 yaş öncesi dönemde birincil nesne, anne ile kurduğu ilişkiye odaklanmaktadır. Bu dönemde bakım veren ile kurulan ilişkide bebeğin tatmin edildiği veya engellendiği deneyimler yaşaması, kendiliğini ve ötekini 'iyi' ya da 'kötü' şeklinde böldüğü savunma mekanizması geliştirmesine neden olmaktadır. Bu nedenle, psikoterapi sürecinde temel olarak borderline kişiliğe sahip danışanın terapi sürecini domine eden nesne ilişkilerinin ortaya çıkarılması hedeflenmiştir ve 'iyi' veya 'kötü' kutuplaşmasının çözülmesi için danışan ile kurulan terapötik ilişkiden yararlanması amaçlanmıştır. Bu makalede, nesne ilişkileri teorisi çerçevesinde borderline kişilik örgütlenmesine sahip Beril M. ile yapılan psikoterapi süreci yorumlanmıştır.
\end{abstract}

Anahtar Kelimeler: nesne iliş̧kileri, borderline örgütlenme, Otto Kernberg

*İletişim: hgundogan134@yahoo.com

Gönderim Tarihi: Şubat 2016

Kabul Tarihi: Mayıs 2016 


\section{Nesne İliş̧kileri Kuramı Çerçevesinden Borderline (Sınır) Kişilik Örgütlenmesine Bakış: Vaka Örneği ile Psikoterapi Sürecinin Yorumlanması}

\section{Giriş}

Makalede öncelikle nesne ilişkileri kuramı, temel olarak Kernberg'in, Freud'un dürtü kuramı ve Klein'ın nesne ilişkileri kuramı arasında kurduğu bağlantı ile açıklanacak, temel kavramlara yer verilecektir. Daha sonra Beril M. vaka örneğinin yaşantısal bilgileri verilerek borderline (sınır) kişilik örgütlenmesinin Kernberg kuramına göre tanımı yapılacaktır. Son olarak, vaka formulasyonu ve psikoterapi süreci nesne ilişkileri kuramına göre yorumlanacaktır.

Nesne ilişkileri kuramını tanımlamadan önce, nesne kavramına yer veren Freud'un dürtü kuramından bahsetmek yerinde olacaktır. Kurama göre, dürtünün bedensel bir kaynağı ve doyuma ulaşma amacı vardır. Bu kaynak ve amaç genetik olarak doğuştan belirlidir. Kaynak ve amaca ek olarak, dürtünün amacını gerçekleştirmek için yöneldiği bir nesnesi vardır ki bu nesne, kaynak ve amacın aksine hem çeşitlilik gösterir hem de çevresel etkiye açıktır (Freud, 1905). Freud (1905), bebeğin ilk sevgisinin annesinin 'meme'sine karşı olduğunu belirtmiştir ve bu sevginin bebeğin ileriki yaşlarında kuracağı bütün sevgi ilişkilerinin modeli olduğunu ileri sürmüştür. Freud (1914) daha sonra, erken dönem sevginin oral sevgiden daha öte olduğunu belirtmiştir. Freud'a göre, anne bebeğini okşayarak, öperek ve sallayarak bebeğine sevmeyi öğretme görevini yerine getirmektedir. Freud'a göre (1914), ilk nesne seçimi anaklitiktir. Anaklitik terimi, başkalarına duyulan bağımlılıkla nitelenen ilişkiler için kullanılmaktadır. Freud, bebeğin annesi yokken ya da yanından ayrılmak üzereyken kaygılandığını gözlemlemiş ve ayrılığın bebeğin fiziksel ihtiyaçlarının doyurulmayacağı yönündeki tehlikeyi işaret ettiğini belirtmiştir.

Nesne ilişkileri teorisi Freudyen psikanalitik kuramın devamı olarak odağı, ilişkilerin kişilerarası ilişkileri değil, zihinde oluşan temsilleri işaret etmesine çekmiştir (Yeomans ve Levy, 2002). Nesne ilişkileri kuramcılarına göre bebeğin kendisine bakım veren kişi (birincil nesne) ile dil-öncesi dönemde ( 0 - 3 yaş) kurduğu ilişki kişilik gelişimi açısından önem taşımaktadır. Bu dönemde bebeğin kendisine bakım veren kişi ile kurduğu ilişkiye bağlı olarak çocuk benlik imgesi geliştirmektedir (Ainsworth, 1969).

Nesne ilişkileri kuramının öncüsü Klein'e göre (1975), bebekler sırasıyla 'paranoid-şizoid' ve 'depresif' konumlardan geçerler. Klein bu aşamaların kronolojik olarak birbirini izleyen aşamalar olmadığından, gelişimin farklı zamanlarında tekrar tekrar ortaya çıkabilecek durumlar olduğundan bahsetmiştir. 'Paranoid-ş̧izoid' dönemde (0 - 3 ay) bebek içindeki saldırgan dürtüleri, 'kötü' yanlarını azaltabilmek için yansıtmalı özdeşim savunması ile nesneye, anneye, yansitarak kendinden uzaklaştırmaya çalışır. Bu dönemde 'kötü', annedir. Klein'a (1975) göre yansıtmalı özdeşimde, bebek bölme mekanizması ile kendiliğin 'kötü' kısımlarını kendiliğinden uzak tutarak anne ya da anne memesinin içine yansıtmaktadır. Böylelikle bebek, kendi ile ilgili 'kötü' kısımların annesinde var olduğunu hissetmektedir. 'Depresif' dönemde ise (3 - 6 ay) bebek, benlik ve nesne temsillerini 'iyi' ve 'kötü’nün bütünleşmiş hali olarak görmeyi başarması ile birlikte, 'paranoid-şizoid' dönemde anneyi 'kötü', 'iyi’ özellikleri olmayan biri olarak gördüğü için suçluluk duyar. Bebeğin zamanla hem saldırgan hem de cinsel dürtülerini aynı nesneye, anneye, yöneltmesi bebekte ikileme neden olmaktadır. Bebeğin nesneyi hem sevgi nesnesi hem de cezalandırıcı nesne olarak görmesi çift-değerlilik yaşadığını göstermektedir (McWilliams, 2013).

Klein'e göre (1975), nesneler 'iyi’ ve 'kötü’ olmak üzere bölünerek (splitting) içe atılırlar. Erken dönem deneyimleri için kısmi nesne, Freudyen psikanalitik kuramında da olduğu gibi anne 'memesi' olarak görülmektedir. Bebek açken, ihtiyacı olduğunda onu doyuran meme 'iyi meme' olarak hafizada depolanırken, ihtiyacı olduğunda orada olmayan, beslemeyen meme 'kötü meme' olarak kaydedilmektedir. Nesne ilişkileri kuramına göre, sadece nesne benliği değil, çocuğun benliği de kendisine bakım veren, 
birincil nesneden aldığı pozitif ve negatif tepkilere göre ‘iyi ben’ ve 'kötü ben’ olarak ayrılmaktadır.

Freud'a göre (1917), ölüm ve terk gibi olaylar sonucu kaybedilen nesneyi yaşatma arzusu ile kişi, içe atma mekanizması vasıtası ile nesnenin temsilini içeride oluşturmaktadır. Klein'in (1975) bahsettiği içe atma mekanizması da Freud'un belirttiği gibi bir savunma mekanizması olmakla birlikte, Klein kuramında savunmanın, çocuğun içindeki saldırgan dürtüleri yatıştırmak gibi bir görevi vardır. Oral dönemde bebeğin benliği ile nesne benliği arasında kesin bir ayrım olmamasından dolayı, nesnenin 'iyi' ve 'kötü' olarak bölünmesi, benliğin de 'iyi' ve 'kötü’ olarak bölünmesi anlamına gelmektedir (Göka, Yüksel ve Göral, 2006). Oral dönem, bebeğin kendisine bakım veren kişi ile güvenli bir bağlanmanın oluşmasını amaçlayan dönemdir. Oral dönemde bebeğin doyumunun sağlanmasının, bebeğin ileriki dönemlerde bağımlı olmayan, insanlara güvenen, kendisine önem ve değer veren bir kişi olmasını sağladığı görülmektedir (Ainsworth, 1969).

Bir diğer nesne ilişkileri kuramcısı Kernberg (1975), psikanalitik dürtü teorisi ile nesne ilişkileri kuramı arasında bağlantı kurmaya çalışmıştır. Kernberg, içselleştirme süreci aracıllğı ile bakım veren nesne ile bağlılık ilişkisinden elde edilen temsili modellerin kişiliği ifade ettiğini varsaymıştır. Bu görüşte Kernberg, Klein'ın (1975) kısmi nesne ile kurulan ilişkiyi içeren kuramını işaret etmiştir. Kernberg, nesne ile edinilen erken dönem deneyimlerin hafizada depolandığını (içselleştirildiğini) ve bunların üç bölümden oluştuğunu ileri sürmüştür. Ruhsal yapının temel yapı taşlarını oluşturan bu üç bölüm kendilik, dürtü veya dürtüyü yansıtan duygulanım ve anlamlı öteki, nesne, olarak tanımlanmakta ve 'nesne ilişkileri ikilisi' olarak adlandırılmaktadır. Nesne ilişkileri ikilisini oluşturan öğeleri daha doğru tanımlamak gerekirse, nesne ilişkileri zihinde oluşan olaylar olarak tanımlandığ için, benlik ve nesne yerine bunların temsillerinden bahsetmek daha yerinde olacaktır (bkz. Figür 1).

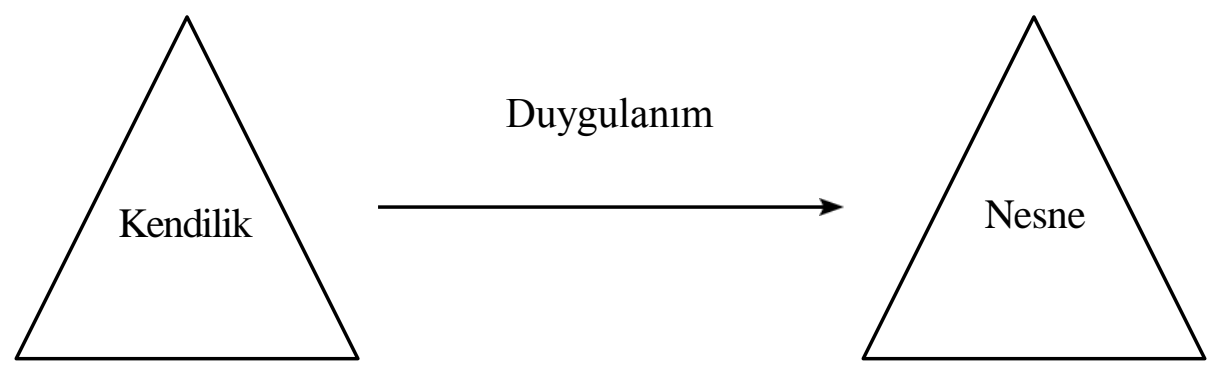

Figür 1. Nesne ilişkileri ikilisi

Kaynak: Yeomans ve Levy, 2002, s. 77

Kernberg kuramında Jacobson (1964) ve Mahler, Pine ve Bergman'ın (1975) bahsettiği ayrılmabireyleşme dönemine de önemli bir yer vermiştir. Ayrılma-bireyleşme, nesne sürekliliğine öncülük eden dönemdir. Ayrılma-bireyleşme döneminde, kendilik ve nesne temsilleri, duygusal değerliği ile birlikte kişilik örgütlenmesini oluşturmaktadır. Mahler vd.'nin kavramsallaştırdığı gibi, Kernberg 0 - 18 ay arasında bebeğin bireysel bir kendilik duygusuna sahip olmaması nedeniyle, annesi ile "ortak yaşamsal bir iç içe geçmişlik" durumundan bahsetmektedir (Mitchell ve Black, 2012, s. 192). Ayrılma-bireyleşme sürecinde çocuk benlik becerilerini geliştirerek özel bir kendilik oluşturmaya başlar. Bu sürecin sağlıklı geçirilmesi ile birlikte kendilik imgeleri ve nesne imgeleri birbirinden ayrılır. Bu ayrılma, iyi ve kötünün bütünleşmesine, kendiliğindeki ve nesnelerdeki belirsizliğe, farklıllı̆a ve karşıtlı̆̆a tolerans geliştir mesine olanak sağlamaktadır (Kaslow ve Magnavita, 2002).

Jacobson (1964) ve Mahler vd. (1975) ile uyumlu olarak gelişim sürecine bakıldığı zaman, bebeğin tatmin edildiği ve engellendiği birçok deneyim yaşadığı söylenebilir (Blom ve Bergman, 2013). Örneğin; bebek açken annesinin bu açlığa cevap vermesi bebeğin tatmin olduğu bir deneyim olarak görülmektedir. 
Bebeğin engellendiği deneyime bakıldığı zaman, bebeğin açlığına herhangi bir sebepten ötürü annenin cevap vermemesi görülmektedir. Nesne ilişkileri ikilileri çerçevesinde, tatmin edici deneyimlerin tatmin olan kendilik ve tatmin eden, besleyen nesnenin pozitif imgesini içerdiği görülmektedir. Buna karşın, engellenmiş deneyimlerin muhtaç olan kendilik ve mahrum eden nesnenin negatif temsilini içerdiği söylenebilir (bkz. Figür 2) (Clarkin, Yeomans ve Kernberg, 2006).

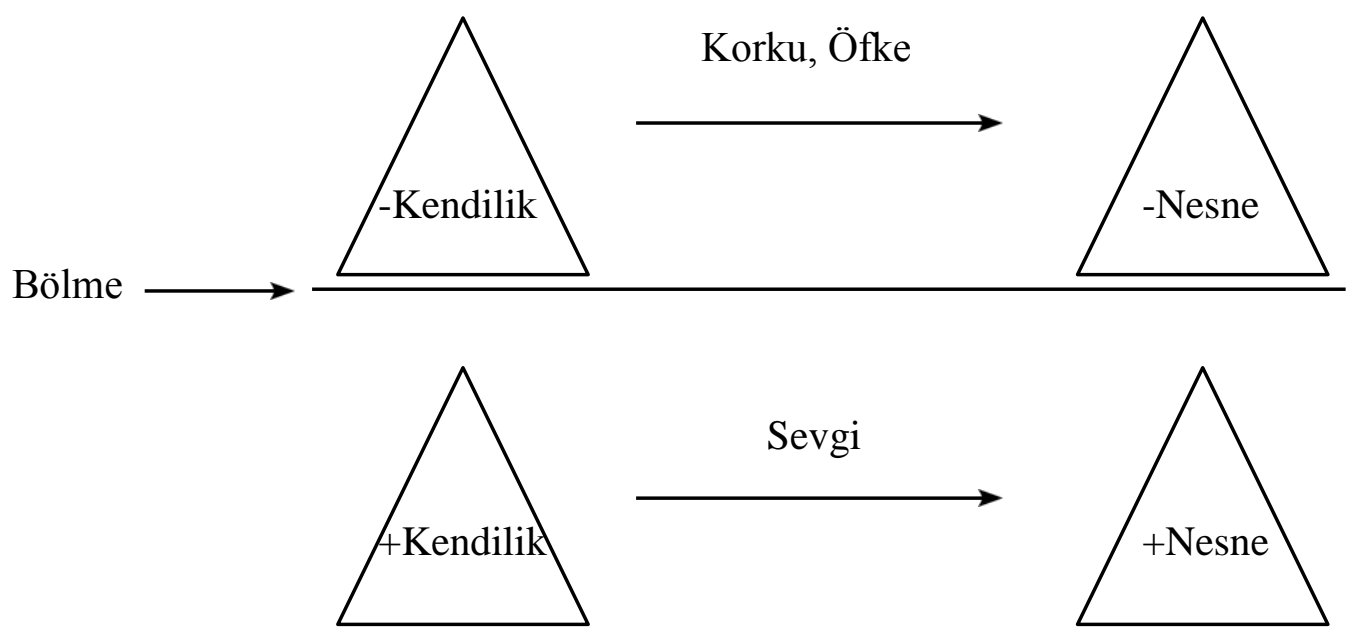

Figür 2. Engellenen (üst) ve tatmin edilen (alt) bebeğin duygulanımı ile birlikte bölünmüş kendilik ve nesne temsilleri Kaynak: Yeomans ve Levy, 2002, s. 77

Bebeğin gelişim sürecine bakıldığında, bebeğin psişesinin bir bölümünün tatmin olduğu deneyimlere dayanarak idealize ettiği imgelerle, diğer bölümünün ise engellendiği deneyimlere dayanarak değersizleştirdiği imgelerle oluştuğu varsayılmaktadır (Kernberg, 1980). Bu bölümlerin aktif şekilde ayrılması psişe içinde olmaktadır. Bu ayrımın temel amacı, idealize edilen temsillerin değersizleştirilen temsillerden korunmasını sağlamaktır. İdealize edilen temsiller, tatmin eden nesneye karşı hissedilen sevgi dolu duygulardan oluşmaktayken; değersizleştirilen temsiller, mahrum bırakan nesneye karşı duyulan nefret ve öfke duyguları ile doludur. Bu ayrım, bölme savunmasının iç mekanizması olarak görülmektedir (Kernberg, 1980). K lein'ın (1975) kuramında bahsettiği gibi, nefret, zarar verme isteği ile tanımlandığı için; iyi ve kötü bölümlerin ayrılmasının iyi kendilik ve nesne temsillerini, kötü temsiller tarafından zarar verilme tehlikesinden korumak için gerekli olmaktadır.

Normal gelişim süreci içerisinde, 1 - 3 yaş aralığında 'iyi' ve 'kötü' bölümlerin bütünleşmesi yer alır. Bebeğin iç dünyası bu bölme ile tanımlanmamakta, bunun yerine 'iyi’ ve 'kötü’ yönlerin bütünleştiği kendilik ve nesne temsilleri bebeğin iç dünyasında yer almaktadır (bkz. Figür 3). Böylelikle, bebeğin dış dünya karmaşasına daha kolay adapte olabileceği esnek bir kişilik geliştirmesine olanak sağlanmaktadır (Kernberg, 1980). Bu süreç, Klein'ın (1975) kuramında yer alan 'depresif’ döneme denk gelmektedir. Eğer depresif duruma neden olan bu bütünleşme gerçekleşmezse, borderline (sınır) kişiliğe neden olan bölme savunma mekanizması devam eder. 

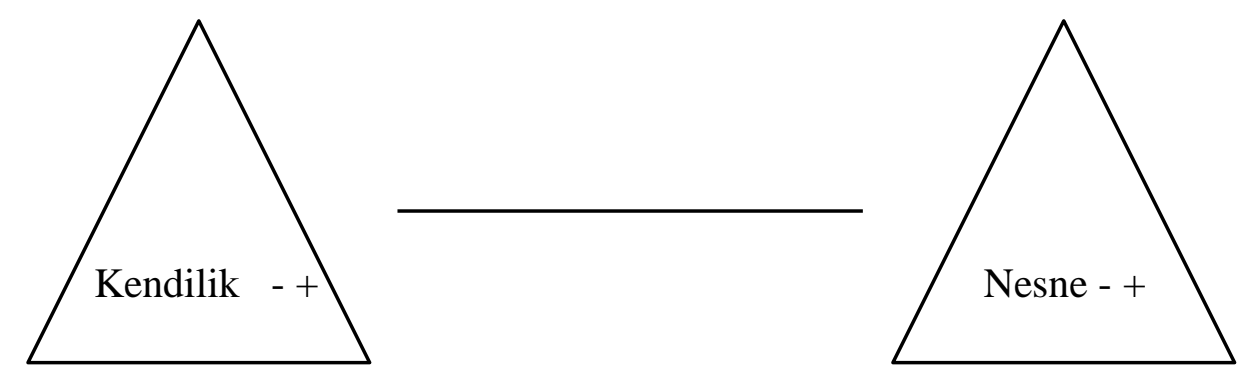

Figür 3. Bütünleştirilmiş kendilik (tatmin olmuş) ve nesne (yeterince iyi) temsilleri Kaynak: Yeomans ve Levy, 2002, s. 77

Makalenin bundan sonraki kısmında Beril M. vaka örneğinin aile, eğitim ve iş hayatı, romantik ve sosyal ilişkileri hakkında bilgi verilecektir.

\section{Vaka Çalışması}

32 yaşında bekar bir kadın olan Beril M., yüksek lisans eğitimi sonrası Ankara' da 2 yıldır tasarımcı olarak çalışmakta ve tek başına yaşamaktadır. Beril M.'nin annesi 61 ve babası 64 yaşında hayatta olup şu anda Bursa'da beraber yaşamaktadırlar. İkisinin de emekli olduğunu belirten Beril M., annesinin ve babasının memur olarak çalıştı̆ıını söylemiştir. Beril M.'nin ablası 35 yaşında evlidir ve İzmir'de yaşamakta ve özel sektörde çalışmaktadır.

Eski erkek arkadaşından ayrılmasıyla birlikte psikolojik ve somatik şikayetler yaşadığını belirten Beril M., psikoloğa gittiğini ifade etmiştir. 2014 Mayıs tarihinde psikoterapiye başladığını belirten Beril M., işi nedeniyle şehir dışına gitmesi gerektiği için 3 seans sonra terapiyi bırakmak zorunda kalmıştır.

\section{Başvuru Nedenleri}

AYNA Klinik Psikoloji ve Destek Ünitesi’ne, erkek arkadaşından ayrılma sürecindeyken en yakın kız arkadaşı ile yaşadığı tartışma sonucu geçirdiği ve 2 yıldır devam etmekte olan panik atak şikayeti ile başvuruda bulunmuştur. Atakların döngüsü anlaşılmaya çalışıldığında, Beril M.'nin gün içerisinde eski erkek arkadaşı ile ilgili haberlere maruz kalması ve bunun sonucunda ayrılık süreci ve yaşadıkları ile ilgili ruminasyon yapması sonucu çoğunlukla gece uyku esnasında atak geçirdiği görülmüștür. Belirtiler olarak vücutta karıncalanma, göğüs sıkışması, nefes almada zorluk ve ölüm korkusu görülmüştür. 2013 Ekim tarihinde yaşadığı ilk panik atak nedeniyle psikiyatriste gittiğini ifade eden Beril M., Lustral kullanmaya başladığını ancak 2 ay sonra ilaca bağımlı olmak istemediği için ilacı bıraktığını ifade etmiştir.

İlk görüşme sonrası, ilerleyen seanslarda Beril M.'nin insanlara karşı güvensizlik şikayeti gündem olmuştur. Güvensizlik şikayetinin geçmişine bakıldığı zaman, Beril M.'nin eski erkek arkadaşı ile ayrıldıktan sonra eski erkek arkadaşının kendisine 'Benim arkamdan konuşuyormuşsun.' ifadeleri ile dolu bir e-mail atması üzerine çevresindeki yakın arkadaşlarına olan güvenini bile yitirmesi söz konusudur. Ayrıca, en yakın kız arkadaşının yurtdışındaki yüksek lisans eğitimi sonrası Türkiye'ye döndükten sonra tanıyamadığı, sevmediği biri haline dönüşmesi de Beril M.'ye insanların olumsuz yönde değişebileceğini 
göstermiştir ve kendisinin insanlar ile güvene dayalı bir ilişki kurmasında zorluk yaşamasına neden olmuştur. Beril M. güvensizlik hissini, "Daha bir insanlara güveniniz kayboluyor en yakın arkadaşınızdan bunu görünce.” ifadesiyle anlatmıştır. Güvensizlik hissiyle ilişki olarak Beril M. ilişkilerinde kullanılacağını düşündüğünü ve bu nedenle insanlar ile iletişim kurmada zorluk yaşadığını belirtmiş̧ir. İlişkilerinde zorluk yaşaması ile ilgili olarak Beril M., "Eskiden herkes beni sevsin isterdim. İyi olmaya gerek yok, biraz da kötü olayım artık diye düşünüyorum. İnsanlar bugüne kadar beni kırmamayı hiç düşünmedi, ben de artık düşünmeyeyim diyorum.” şeklinde ifadeler kullanmıştır.

İnsanlara karşı hissettiği güvensizlik hissinin yanı sıra, Beril M.'nin öfkesini kontrol edemeyerek yıkıcı bir şekilde göstermesi durumu söz konusudur. Beril M.'nin, ilerleyen seanslarda gündem olan eleştirildiği zaman sinirlenmesi ve bu sinirini öfke patlaması yaşayarak göstermesi durumu mevcuttur. Örneğin; başkalarının arkasından konuşulduğu ortamda Beril M.'nin sesini yükselterek “dedikodu yapan” kişiye kızması ve tartışma uzadıkça öfkesini kontrol edemeyerek bağırması ve vücudunda titremenin başlaması durumu söz konusudur.

Özellikle eski erkek arkadaşı ile yaşadığı sarsıcı ayrılık sürecinin ardından Beril M., intihar planları yaptığını ve jilet ile kollarını keserek girişimlerde bulunduğunu belirtmiştir. Eski erkek arkadaşını kaybetmemek için onun cinsel fantezilerini kabul ettiğini ve bu nedenle kendisinden "tiksindiğini, nefret ettiğini”" söyleyen Beril M., intihar düşüncesinin asıl sebebinin bu olduğunu ifade etmiştir. En son intihar girişimi 2014 Aralık tarihinde kollarını jiletle keserek olmuştur. En son intihar planını ise, 2015 Şubat tarihinde yapmıştır. İntihar girişimlerinden ailesinin haberi olmadığını söyleyen Beril M., "Cesaretsiz bir insanmışım.” ifadesi ile özellikle annesini üzmek istemediği için girişimlerini tamamlamadığını belirtmiştir.

15. seansta Beril M.'nin gündeme getirdiği bir diğer şikayet, ' 3 harfliler' ve karabasan korkusu olmuştur. Çocukluk döneminde arkadaş ortamında konuşulan bir konu olduğunu belirten Beril M., evde yalnız kaldığı zaman yatağında yatmak yerine salonda televizyon karşısında ve ışık açık şekilde yattığını ve bu nedenle uyku düzeninin bozuk olduğunu ifade etmiş̧tir. Ancak, evde biri olduğu zaman, özellikle annesi ile aynı yatakta yattıkları zaman bu korkuyu yaşamadığını söylemiştir.

Kendisi ile haftada bir olmak üzere 27 seans yapılmış olup terapi süreci devam etmektedir.

\section{Aile Yaşantısı}

Beril M., annesini iyi kalpli, melek gibi bir insan olarak tanımlamıştır. Annesinin aile içerisinde pasif rolde olduğunu söyleyen Beril M., kendisi babası ile bir tartışma yaşadığı zaman annesinin babasından yana arabulucu rolünü üstlendiğini dile getirmiştir. Aile içinde annesi ve kendisinin birbirleri için "bir numara" olduğunu belirten Beril M., annesine her şeyini anlattığını ifade etmiştir. Annesinin erken yaşta anne ve babasını kaybetmesi ile, babasına karşı annesini koruyacak kimsenin olmaması üzerine annesini savunma ve koruma rolünü üstlendiğini belirten Beril M., babasına karşı annesini mağdur durumda gördügünü ifade etmiştir. Annesini savunup korudukça aralarındaki bağın kuvvetlendiğini belirten Beril M., annesinin çocukluk döneminden itibaren ablasının ihtiyaç ve isteklerine hemen cevap verdiğini ancak kendi ihtiyaç ve isteklerine koşullu cevap verdiğini dile getirmiştir. Örneğin; kendisine gitar alınmasını istediğinde annesi "Dönem sonu notların iyi gelirse alırız." derken, ablası kendisine kıyafet alınmasını istediğinde annesinin hemen ablasının istediklerini aldığını belirtmiştir. İkinci plana itildiğini hissettiğini belirten Beril M., bu nedenle annesine karşı yoğun bir hayal kırıklığı hissinin mevcut olduğunu ifade etmiştir. Burada, Beril M.'nin ilk seanslarda belirttiği annesinin 'bir numarası' olmak ile ilgili ifadesi ile çeliştiği görülmüştür.

Babasının erkek çocuk istediği ve kendisi doğunca 6 ay boyunca babasının, yüzüne bakmadığı, kucağına almadığı bilgisini annesinden edindiğini belirten Beril M., çocukluk döneminden itibaren babasının sevgisini kazanmak için sevgisini ona çok fazla gösterdiğini ve babasının istediği şekilde yaşadığını dile getirmiştir. Babasının kendisini ailenin erkek çocuğu gibi yetiştirdiğini belirten Beril M.’nin giyim tarzında, 
konuşmasında ve davranışlarında bunun izlerini taşıdığı gözlemlenmiştir. Babasının annesine ve ablasına bağırmasına birçok kez tanık olan Beril M., babası kendisine kızmasın diye sessiz kaldığını, ne isterse onu yaptığını ve derslerinde başarılı olmaya çalıştığını ifade etmiştir. Babasının kendisi için hep iyi bir baba olmaya çalıştığını belirten Beril M., babasının gözünde kendisinin "bir numara" olduğunu söylemiştir. Bunu da ablasının babasına yalan söylemesine, kendisinin ise dürüst olmasına bağlamıştır. Çocukluk döneminde babasının annesini aldattığını, zaman zaman annesine fiziksel şiddet uyguladığını belirten Beril M., babasının her zaman 'Millet ne der?' endişesini taşıdığını ifade etmiştir. Üniversite döneminde ayrı eve çıktıktan sonra babasıyla bağlarının zayıfladığını belirten Beril M., erkek arkadaşından ayrıldıktan sonra erkeklere karşı güvensizlik duymasıyla birlikte babasına karşı nefret ve öfke duygularının ön plana çıtığını "Babamın konuşması bile beni evde irrite ediyordu." ifadesi ile anlatmıştır.

Ablasını, kendi isteklerini yaptırmaya çalışan, istekleri yerine gelmediği zaman da öfkelenen ve bağırıp çağıran biri olarak tanımlayan Beril M., ablası ile olan ilişkilerini "Dönüp baktığımda hayatım, hep onun arkasını toplamak ile geçmiş." ifadesi ile anlatmıştır. Çocukluk döneminden itibaren ablasının kendisini sevdiğini hiçbir zaman hissedemediğini belirten Beril M., ablasının kendisini kıskandığını ve küçük düşürmeye çalıştığını ifade etmiştir. Çocukluk döneminde ablasının kendisini dövdüğünü belirten Beril M., bu dönemden beri kendisinin istenmeyen kardeş olduğundan bahsetmiştir. Ablasının kendisi hakkında başkalarına yalanlar söylediğini ifade eden Beril M., ablasının kendisinden nefret ettiğini hissettiğini dile getirmiştir. Beril M., ablasının kendisini özellikle annesine karşı kötülediğini, kendisi hakkında yalanlar söylediğini ve kendisini sürekli açıklamak zorunda kaldığını dile getirmiştir.

\section{Okul ve İş Yaşantısı}

Üniversite dönemine kadar ailesiyle birlikte Bursa'da yaşayarak eğitimine devam eden Beril M., eğitim hayatının başarılı geçtiğini belirtmiştir. Beril M., üniversiteyi Ankara'da Tasarım bölümünde okumuş ve ailesinden ayrılarak yurtta daha sonra da kendi evinde kalmaya başlamıştır. Beril M., lisans eğitimi sonrasında yüksek lisans için yurtdışına gitmiş ve 3 sene kaldıktan sonra ailesinin yanlarına dönmesi için baskı yapması nedeniyle yurtdışında yaşamak istemesine rağmen geri dönmüştür.

Yüksek lisans eğitimi sonrası işe başlayan Beril M., 2 senedir Tasarımcı olarak çalışmaktadır. İşini değiştirmeyi planladığını söyleyen Beril M., iş yerinde çoğu insanın başkalarının arkasından konuştuğunu ancak yüzlerine güldüğünü, kendisinin böyle bir insan olmadığı için zorlandığını belirtmiştir.

\section{Romantik İlişkiler}

Beril M.’nin ilk ciddi ilişkisi 6 sene sürmüştür. Bu ilişkiyi sevgi, bağlılık ve güven ilişkisi olarak tanımlayan Beril M., ilişkide tartışmaların çok fazla yaşanmadığı ve yaşandığı zaman da çözüme kavuşturduklarını ifade etmiştir. Yüksek lisans eğitimi için yurtdışına gittiği dönemde eski erkek arkadaşı kıskançlık ve güvensizlik nedeniyle problemler yaratmış ve uzakta oldukları için bu problemleri çözüme kavuşturmada zorluk yaşamışlardır. Kıskançlık ve güven problemlerinin artması nedeniyle ilişkide huzursuz olan Beril M.'nin bu dönemde ilgisi başka birine kaymaya başlamış ve eski erkek arkadaşı ile olan ilişkisini bitirmiştir.

Beril M.'nin ilk görüşmelerde "malum kişi”' olarak bahsettiği bir sonraki erkek arkadaşı ile olan ilişkisi 2 sene sürmüştür. Yurtdışında yaşadıkları 1 sene boyunca hayatının merkezine sevgilisini koyan Beril M., bunu “Annem, babam, her şeyim o olmuştu." şeklinde anlatmıştır. Eski erkek arkadaşı ile olan ilişkisinin aşk, bağımlılık, kıskançlık ve değersizlik duygularıyla kaplı olduğunu belirten Beril M., ilişki boyunca kendisinin hep kullanıldığını hissetmiştir. 3 kere aldatılan ve sevgilisini kaybetmek istemediği için her defasında erkek arkadaşını affeden Beril M., cinsel açıdan onu tatmin etmek adına başka kadınlarla 
kurduğu fantezilerini kabul etmiş ve istemediği bir kişi haline dönüşmüştür. İlişki içerisinde sanki bir yerde kopacaklarmış gibi hissettiğini belirten Beril M., bu hissi sevgilisine Türkiye'ye dönerken "Uçaktan indikten sonra postalarsın beni artık." şeklinde ifade etmiştir. Türkiye'ye döndükten sonra sevgilisi, 'Beni boğdun, yeter artık.' diyerek ayrılmak istediğini söylemiştir. Sevgilisinin ayrılma isteğinden sonra kollarını jiletle keserek intihar girişiminde bulunduğunu belirten Beril M., düşüncelerini "Gayem yok, hayatta beni tutan bir şey de yok. Aile de bir yere kadar, aradığınızda onları bile bulamayabiliyorsunuz.”, "Bana Tanrı'nın verdiği bir cezaydı bu.", "Bu kadar sevilmemeyi ne yaptım da hak ettim?” şeklinde ifade etmiştir.

\section{Sosyal Yaşantısı}

Görüşmelerde Beril M.’nin, sosyal ilişkilerinin ve aktivitelerinin fazla olmadığı gözlemlenmiştir. Çevresindeki kişilerin, özellikle iş yerindeki insanların, hayatlarıyla ilgilenmeyen ve iletişimini sınırlı tutan Beril M., başkalarının arkasından konuşulduğu ortamlarda bulunmamaya özen göstermektedir. Beril M., bunu "Başkalarının arkasından bu şekilde konuşan insanlar, kim bilir benim arkamdan neler diyorlardır?" şeklinde ifade etmiştir. Bu durumun, Beril M.'nin insanlara karşı hissettiği güvensizlik duygusunun dile getirilmiş hali olduğu söylenebilir. Beril M., kendisinin arkasından konuşulmasının, kendisini tanımayan ya da az tanıyan kişilerin kendisi hakkında önyargı oluşturmalarına ve kendisine tavır almalarına neden olacağını düşünmektedir ve bunu "Birisi beni kötü niyetle algıladığı zaman çok üzülüyorum, yıkılıyorum." şeklinde ifade etmiştir. Kendisinin bulunmadığı ortamlarda kendisi hakkında konuşulduğundan emin olduğunu söyleyen Beril M., bulunduğu ortamlarda ne zaman kendisine laf söyleneceği endişesi yaşamaktadır. Bu nedenle ortamda enerjisi düşük, konuşmak istemeyen, ortamdan ayrılma isteğiyle dolu biri olmaktadır.

Beril M.’nin başvuru nedenleri ve geçmiş yaşantıları göz önüne alındığında paranoid özellikler gösteren borderline kişilik örgütlenmesine sahip olduğu görülmektedir. Makalenin bundan sonraki kısmında borderline kişilik örgütlenmesi DSM-V ve Kernberg kuramına göre tanımlanacak ve Beril M. vakası nesne ilişkileri kuramı çerçevesinde incelenecektir.

\section{Borderline (Sınır) Kişilik Örgütlenmesi}

DSM-V tanı kriterlerine göre, borderline kişilik bozukluğunun temel özelliği kişilerarası ilişkilerde, kendilik imgesinde ve duygu durumda değişken ve yaygın bir örüntünün görülmesi ve erken yetişkinlik döneminde başlayan ve çeşitli durumlarda kendisini gösteren bir dürtüselliğin olmasıdır. Kadınlarda erkeklere göre ağırlıklı olarak (yaklaşık \%75) daha fazla görülmektedir (American Psychiatric Association [APA], 2013). DSM-V tanı kriterlerine göre, $\tan 15$ veya daha fazla kriterin var olması durumunda konulmalıdır. Vaka örneğine bakıldığı zaman, Beril M.'nin erkek arkadaşı tarafından gerçek ya da imgesel terk edilmeden kaçınmak için çaba sarf ettiği görülmektedir (Kriter 1). Beril M.'nin erkek arkadaşından ayrılma sürecinde kollarını jilet ile keserek yinelenen intihar davranışları ve girişimleri olmuştur (Kriter 5). Özellikle başkalarının arkasından konuşulduğu ortamlarda Beril M.'nin duygu durumundaki dikkat çeken tepkiselliği nedeni ile çabuk öfkelendiği ya da kendisinin arkasından konuşulduğu düşüncesine eşlik eden kaygıya sahip olduğu söylenebilir (Kriter 6). Beril M. ayrıca boşluk duygusu yaşama (Kriter 7) ve uygunsuz, yoğun bir öfke ya da öfkeyi kontrol etmede zorluk yaşama (Kriter 8) durumu içerisindedir. Son olarak, Beril M. yoğun stresli dönemlerinde kullanıldığı ve arkasından konuşulduğu şeklinde geçici paranoid düşünceler gösterebilmektedir (Kriter 9) (APA, 2013).

DSM-V'de kullanılan bozukluk tanımının tersine, Kernberg'in (1975) kuramına göre borderline, bir ucunda nevroz, bir diğer ucunda psikozun yer aldığı kişilik örgütlenmesi ekseninde, nevroz ve psikozun arasında yer alan bir kişilik yapısı düzeyidir. Kernberg, borderline kişilik örgütlenmesini kimlik dağılması 
(tutarsız ve çelişkili benlik ve öteki algısı), ilkel savunmaların kullanılması (çoğunlukla bölme ve yansıtmalı özdeşim) ve gerçeği değerlendirme yetisinde eksiklik ler ile karakterize olan güçsüz benliğin (yetersiz dürtü kontrolü ve kaygı toleransında düşünklük) yer aldığı kişilik örgütlenmesi olarak tanımlamaktadır. Kernberg'e göre borderline örgütlenmeye sahip kişilerde, yalnız oldukları dönemde yoğun bir boşluk hissi görülmektedir.

Beril M.'nin Kernberg'in borderline kişilik örgütlenmesi tanımlamaları ile uyumlu özellikler göstermesine paralel olarak, güçsüz benliğe sahip olduğu için hayatındaki anlamlı öteki kişiler (özellikle annesi ve erkek arkadaşları) tarafindan kabul edilmeye ya da reddedilmeye hassas olduğu gözlemlenmiştir. Kendi isteklerine ters düşen durumlarda Beril M.’nin öfkelendiği ve öfkesini regüle edemediği seanslarda ortaya çıkmıştır. Hayatında öfkenin ön planda olmasına ek olarak, öfke ile dolu olan kaotik durumunu devam ettiren ise, tatmin edilmesini istediği yoğun kişisel ihtiyaçlanı ve benliği ve öteki kişiler hakkındaki düşüncelerinde görülen ani değişimlerdir (Millon vd., 2004).

Bölme savunma mekanizması nesne ilişkileri kuramında da bahsedildiği gibi, Kernberg’ in (1980) borderline kişilik örgütlenmesi tanımlamasında önemli bir yere sahiptir. Bölme savunma mekanizmasında insanların ve durumların karmaşı doğası göz önünde bulundurulmaz. Kernberg'in borderline örgütlenme ile ilgili görüşlerine paralel olarak, bölme bu örgütlenmeye sahip kişilerin kimlik karmaşasını ve pozitif duygulanımdan negatif duygulanıma ani geçiş eğilimlerini açıklamaktadır. Kernberg (1975), bu özelliklerin borderline kişilerin kaotik ilişkilerinin ve yoğun duygularını engellemedeki yetersizliklerinin altında yatan nedenler olduğu görüşünü savunmaktadır. Beril M., hem kendilik temsilini hem de nesne temsilini 'tamamen kötü’ ve 'tamamen iyi' şeklinde ayırmasından dolayı bütünlüklü bir temsil oluşturamamaktadır. Bu nedenle, kendiliğe ve nesnelere dair duygulanımlarında ani geçişler olmaktadır.

Kernberg’e (1975) göre, borderline kişilik örgütlenmesine sahip kişiler, Klein’ın (1975) görüşünde değinilen oral aşamada saplanıp kalan kişilerdir. Erken dönem oral aşamada saplanıp kalan kişiler, kendilerini olduğu gibi, ilişki içine girdikleri insanları da iyi ve kötü olarak bölmektedirler. Kendi 'kötülüklerini' karşılarındaki kişilere yansıtarak paranoid savunmalarla kendilerinden uzaklaştırmaya çalışırlar. İyi ve kötünün bütünleştiği depresif pozisyona geçemezler.

Klein'in oral aşamasına ek olarak, borderline kişilik örgütlenmesine sahip kişiler, Mahler vd.'nin (1975) bahsettiği ayrılma-bireyleşme dönemine saplanıp kalmış kişilerdir. Borderline örgütlenmeye sahip olma olasılığı olan bebek, kalıcı olarak orada bulunan, kendisini besleyen figür imgesini içselleştirmeden önce kendi ve ötekini birbirinden ayıramaz. Bebeğin bu dönemde yaşadığı, annesi yanından ayrıldığı zaman geri dönmeyeceği, tamamen ortadan kaybolacağı korkusudur. Bunun yanı sıra, bebek ayrılma-bireyleşme döneminde anneden ayrıldığı zaman geri döndüğünde anneyi bulamama korkusu da yaşamaktadır. Borderline kişilik örgütlenmesine sahip kişilerin, bebeklik döneminde yaşadıkları anneden ayrılma kaygısını, hayatları boyunca ilişki içine girdikleri diğer kişilerle de tekrarladıkla rı görülmektedir. Bu nedenle, borderline örgütlenmeye sahip kişiler hayatlarında yer alan anlamlı öteki kişilere bağımlı kişiler olarak tanımlanmaktadırlar. Bebeklik dönemindeki anneleri gibi, yetişkinlik hayatındaki eş ya da sevgililerini tekrar görememe korkusu yaşarlar. Bu kişilerin sevgisini kazanmak için çok çaba sarf ederler ancak bu çabaların karşılığını alamadıklarını düşündükleri zaman bu kişiler, nefret ettikleri kişilere dönüşsebilmektedir. Terk edilme ve yalnız kalma korkusu hayatlarına o kadar hakimdir ki bu korkuya eşlik eden kaygı duygusundan kurtulmak için intihara başvurabilirler (Levy vd., 2006). Beril M. için bunun en somut örneğini, yurtdışında erkek arkadaşı ile yaşadığı ilişkide görmek mümkündür. Erkek arkadaşının hayatındaki sürekliliği onun için o kadar belirsizdir ki; hayatının merkezine onu koymasından dolayı erkek arkadaşı ile ayrılma sürecinde hissettiği terk edilmişlik, yalnız kalma ve boşluk duygusu çok yoğun olmuştur.

Ayrılma-bireyleşme döneminin nesne sürekliliğine öncülük eden dönem olması nedeniyle, nesne sürekliliğindeki başarısızlığın altında yatan nedenlere bakmak yerinde olacaktır. Kernberg (1975), borderline örgütlenmeye sahip kişilerin sahip olduğu fazladan 'oral saldırganlığa' dikkat çekmektedir. Kişiler bu 
fazladan saldırganlığa ya yapısal olarak sahiptiler ya da erken dönem ihtiyaçlarının duyarsız bakım verenleri tarafindan engellenmesiyle sahip olurlar. Bu nedenle, 'iyi' ve 'kötü’nün bütünleşmesi kişi için son derece tehditkar olmaktadır. Bütünleşme gerçekleştiği zaman, 'kötü’ imgeye yöneltilmiş olan öfke ve nefretin 'iyi' imgeye zarar vermesi olasıdır. Borderline örgütlenmeye sahip kişiler hayatlarındaki anlamlı ötekilerin bütünleşmiş kavramsallaştırmalarını başarsalar bile; bu bütünleşmiş imge, bütünleşme nin ve bu bütünleşmeyle beraber 'iyi’ nesnenin, iyi annenin, zarar verileceği ya da yok edileceği öfkeye uğramaktadır (Kernberg, 1975).

\section{Nesne İlişkileri Kuramı Çerçevesinden Vaka Formülasyonu}

Beril M.'nin geçmiş yaşantıları dayanak alınarak şu anda yaşadığ semptomlar ile başvuru nedenleri çerçevesinde paraniod özellikler gösteren borderline kişilik örgütlenmesine sahip olduğu düşünülmektedir. Kernberg'e (1975) göre, borderline kişilik örgütlenmesine sahip kişiler, Klein'ın (1975) görüşünde değinilen oral aşamada saplanıp kalan kişiler olmaları nedeniyle, erken dönem oral aşamada saplanıp kalmışlardır. Kendilerini olduğu gibi, ilişki içine girdikleri insanları da iyi ve kötü olarak bölmektedirler. Kendi ‘kötülüklerini' karşılarındaki kişilere yansıtarak paranoid savunmalarla kendilerinden uzaklaştırmaya çalışırlar. Beril M.'nin ilişkilerinde, insanların söz ve davranışlarına gerçek dışı bir biçimde kötü niyetli, güvensiz ve kuşku duyma eğiliminde olduğu görülmektedir. McWilliams'1n (2013) bahsettiği gibi, Beril M., patolojisi hakkında sınırı bir farkındalığa sahip olup başvuru nedeni olarak panik atak gibi spesifik bir stres kaynaklı şikayeti işaret etmiştir. Panik ataklarının ilk olarak Beril M.'nin erkek arkadaşından ayrılma sürecinde olması ve o dönemde en yakın kız arkadaşı ile kavga ettiği sürece denk gelmesi Gabbard'ın (1994) belirttiği gibi, atakların Beril M.'nin hayatında anlamlı ötekinin kaybı ile ilişkilendirilebilir. Atakların döngüsü anlaşılmaya çalışıldığında, Beril M.'nin eski erkek arkadaşı ile ilgili haberlere maruz kalması ve bunun sonucunda ayrılık süreci ve yaşadıkları ile ilgili ruminasyon yapması sonucu gece uyku esnasında atak geçirdiği görülmüştür. Buna ek olarak Gabbard, panik atak geçiren kişilerin nesne sürekliliğinde başarı sağlama konusunda problem yaşadıklarını belirtmiştir. Beril M.' de de görüldüğü gibi, erkek arkadaşı ile yaşadığı terk edilme kaygısı danışanda, erkek arkadaşının tamamen ortadan kaybolacağı düşüncesine eşlik etmektedir. Seanslarda kendisi ile kaygısını azaltmak için gevşeme egzersizleri pratik edilerek panik atak geçirdiği sırada bunları kullanması konuşulmuştur.

McWilliams'a göre (2013), bölme savunma mekanizması nedeni ile borderline örgütlenmeye sahip kişiler, olayları ve öteki kişileri terapistin gördüğü gibi bir "bütünleşmiş gözlemleyen ego" ile göremezler (s. 101). Bu nedenle, terapistin gözlemleyen egoya ulaşma çabası, 'iyi’ ve 'kötü' kısımlarını bütünleştirme çabası, Beril M.'nin yapılan müdahaleleri benliğine bir eleştiri olarak alması ve bunu seanslarda "Ben gerçekten o kadar kötü biri miyim?” şeklinde ifade etmesi ile sonuçlanmaktadır. Beril M.'nin eleştiriye karşı duyarlı oluşu, kendisinin 'iyi' biri olmak için çaba sarf etmesine ve 'kötülükleri olan biri' olarak görünmekten korkmasına bağlanmakta olup bu bölmenin 'iyi’ kısmını 'kötü' kısmından koruma görevi üstlendiği varsayılmıştır.

Görüşmelerde Beril M.’nin hayatının her alanına yayılmış olan değersizlik hissi ile kaplı olduğu gözlemlenmiştir. Çocukluk döneminde Beril M.'de annesinin kendisini ikinci plana ittiği ve ablasının kendisini sevmediği, kendisinden nefret ettiği hissi hakim olmuştur. Romantik ilişkisinde, Beril M., eski erkek arkadaşının kendisini reddederek ayrılması sonucunda değersizlik, boşluk ve kimsesizlik duygusu hissetmiş, onu geri getirmeye odaklanarak nerede hata yaptığı sorusuna takılıp kalmıştır. Kernberg'in (1975) bahsettiği gibi, boşluk ve kimsesizlik duyguları, Beril M.'nin, imgesini içselleştirdiği eski erkek arkadaşının yitimi ile çevresinin yoksunlaştığını ve değersizlik, boşluk ve kimsesizlik duygusu ile kendisinin de azaldığını hissetmesine bağlanmaktadır. Bu his, sosyal ilişkilerine de yansımış ve aktivitelerinde azlık olarak seanslarda gözlemlenmiştir. 
Beril M.'nin çocukluk döneminde annesinin, ablasının ihtiyaçlarını doyuruyor ve isteklerini tatmin ediyor olması ancak Beril M.'nin isteklerini koşullar koyarak engelliyor ve tatmin etmiyor oluşu ve ihtiyacı olduğunda orada olmayışı, Beril M.'nin annesiyle olan etkilelşiminde yaşadığı strese çözüm getirememesine ve öfkelenilecek yeni durumlar yaratmasına neden olmuştur. Bu durum Kernberg' in (1975) kuramında değindiği fazladan agresyona örnek teşkil etmektedir. Beril M.'nin erken dönem ihtiyaçlarının duyarsız bakım vereni tarafindan engellenmesiyle sahip olunan fazladan agresyon, 'iyi' ve 'kötü'nün bütünleşmesini kişi için son derece tehditkar kılmaktadır.

Beril M.'nin annesi ile kurduğu ilişkide kaygı duygusunun yoğun olması uyku düzensizliği problemine bağlanabilir. Öyle ki; Beril M.'nin, yalnız kalma korku mekanizmasına bağlı olarak, "3 harfliler"den ve karabasandan korkması durumu mevcuttur. Evde yalnız kaldığı zaman yatakta tek başına yatamaması ve salonda televizyon ve sşık açık şekilde yatması uyku kalitesinde düşüşe neden olmaktadır. Evde birisi olduğu zaman, özellikle annesi, birincil nesne, ve onunla beraber yattığı zaman, Beril M.'nin bu korkuyu yaşamaması annesi ile olan ilişkisi ile bağlanabilir. Çocukluk döneminden itibaren, annesinin ablasının ihtiyaçlarını tatmin etmesi ancak danışanın ihtiyaçlarını engellemesi ve annesinin kaygılarını Beril M.'ye yansıtması, danışanın annesi ile güvene dayalı bir ilişki kuramamasına neden olmuştur.

Çocukluk döneminde Beril M. ablasının karşısında hissettiği yenilmiş ve küçük düşürülmüş olma duygusu mevcuttur. Özellikle ablasının eleştirilerine ve nefretine, babasının annesine ve ablasına fiziksel ve sözel şiddet uygulamasına ve annesinin kaygılarına maruz kalmış olan Beril M.'nin, hırpalayıcı bir aile ortamında büyüdüğü söylenebilir. Ailede, korkutucu ebeveyn olarak babanın bulunmasının doğurduğu duyguları geçirmede Beril M.'ye yardımcı olabilecek kişilerin olmaması Kernberg'in (1975) borderline örgütlenmeye sahip kişilerde tanımladığı, danışanın güçsüz, küçük düşürülmüş ve aşağılanmış bir benlik imgesi geliştirmesine neden olmuştur. Benlik imgesiyle bağlantılı olarak Beril M., sosyal ilişkilerinde küçümseneceği ve kullanılacağı korkusu yaşamaktadır. Beril M., sosyal ortamlarda kendini güvende hissetmemekte ve duygusal enerjisinin büyük bir bölümünü olası tehditleri bulmak için çevresini tarayarak harcamaktadır. Görüşmelerde, Beril M.’nin hayatına hakim olan eleştirel gözün, babasının eleştirel gözü olduğu gözlemlenmiştir. Yeni girdiği ortamlarda utanan, nasıl davranacağını bilemeyen Beril M., davranışlarının başkaları tarafından eleştirileceği yönünde kaygı yaşamakta ve bu kaygı insanların kendisinin arkasından konuştuğu, işler çevirdiği gibi paranoid düşüncelere neden olmaktadır.

Beril M.’nin “eteğinden ayrılmadığı” annesinden ayrılma kaygısını, hayatına giren anlamlı ötekilerle tekrarladığı görülmektedir. Bu nedenle, danışan hayatında yer alan anlamlı öteki kişilere bağımlı olarak tanımlanabilir. Buna bağlı olarak da danışanın genellikle erkek arkadaşlarından, sevgi ve kabule önem verdiği, kendi değerini bu sevgi ve kabule göre şekillendirdiği söylenebilir. Danışanın bu kişilerden sevgi ve kabul görebilmek için ilişkilerinde kendini geri plana atarak erkek arkadaşını ön plana koyması ve ona daha çok değer vermesi söz konusudur. Bu nedenle, bu kişilerle herhangi bir tartışma yaşadığı anda hayatındaki anlamlı ötekileri kaybetme korkusunu yaşamaktadır. Romantik ilişkilerinde değersizlik hissinin bu şekilde hayat bulmasının yanı sıra, sosyal ilişkilerine bakıldığı zaman Beril M.'nin başkalarının kendisi için 'iyi insan' ya da 'kötü insan' şeklinde düşüneceği yönünde değerlendirmeleri olduğu görülmektedir. Arkadaşlarının kendisini 'iyi insan' olarak tanımlamaları için, başkalarının isteklerine 'hayır' diyememe ve başkalarına koşulsuz yardımda bulunma durumu söz konusudur.

\section{Psikoterapi Sürecine Nesne İlişkileri Kuramının Uygulanması}

Genel olarak terapi değerlendirildiği zaman birincil olarak öne çıkan özellik, danışanla sağlam bir çalışma iş birliğinin kurulmuş olmasıdır. Danışanın özellikle başkalarına güvenmekte yaşadığı sorunlar düşünüldüğünde, böyle bir ilişkinin kurulmasının önemli olduğu düşünülmektedir. Kurulan iş birliğinin temeline bakıldığında, danışanın görüşmelerde çocukluk döneminde anne babasından göremediği 
koşulsuz sevgi ve kabulü terapist tarafindan görüp deneyimlemesinin var olduğu görülmektedir. Danışan güven duygusuna dayalı ilişki deneyimini seanslarda yaşamış ve özel hayatında da bunu uygulamaya koymaya başlamıştır. Terapistin paranoid özelliklere sahip danışanla duyarlı bir şekilde çalışıyor olması ve danışanın kendisinin arkasından konuşuluyor ve iş çevriliyor düşüncesine karşı çıkmadan sorgulaması, danışanın paranoid kurgularını sökmeye başlamasını sağlayacak bir onaylanmışlık hissi yaşamasına temel oluşturmuştur.

Beril M. ile terapi sürecinin başlangıcı genel olarak, danışanın yaşadığı semptomları ve kişilik örgütlenmesini anlama üzerine kurulmuştur. Görüşmeler çoğunlukla danışanın seanstaki durumunun üzerinden devam etmiştir. Kernberg’in (1975) nesne ilişkileri kuramının patoloji kavramsallaştırmasına dayanarak, öncelikle terapist ve danışan arasındaki ilişkiyi domine eden nesne ilişkileri terapi sürecinde tanımlanmaya çalışılmıştır. Bu tanımlamayı yapabilmek için, süpervizyonlar ile birlikte terapist aktarımla ortaya çıkan danışanın iç dünyasındaki karmaşıklı̆̆ deneyimleme ve tolere edebilme yönlerini geliştirmiştir. Nesne ilişkileri terapi sürecinde tanımlanarak danışanın bütünleştirilmiş bir kendilik algısı kurması amaçlanmıştır. Bütünleştirilmiş kendilik algısı ile, danışanın duygularını regüle etmesi hedeflenirken ayrıca bütünleştirilmiş öteki algısı ile diğer kişileri kusurları ile kabul edebilmesi hedeflenmiştir.

Beril M., ilk seanslarda terapistten hemen ilgi bekleyen yoğun bir ihtiyaç ile aktarım davranışı göstermiştir. Örneğin; Beril M.’nin terapiden beklentisi yaşamakta olduğu acının, eski erkek arkadaşından ayrılma acısı, hızlı bir şekilde giderilmesidir. Aktarımın yoğun olarak hissedildiği durumlarda terapist kendisine 'Şu anda ben danışan için kimim?' sorusunu sorarak danışanın nesne ilişkilerini anlamlandırmaya çalışmıştır. Seans odasında aktarımla ortaya çıkan nesne ilişkileri gündem edildikten sonra terapist danışanın değişken taraflarını ve duygulanım hallerini gözlemleme ve yorumlama aşamasına geçmiştir. Örneğin; danışanın başkasının arkasından konuşulduğu ortamdaki kişilere öfke göstermesi ancak başka bir arkadaş ortamında kendisinin de başkasının arkasından konuşması rolleri danışan ile yorumlanmıştır.

Terapinin ilerleyen seanslarında terapist, birbirine karşı savunulan nesne ilişkileri ikilileri arasındaki bağlantıyı gözlemleyerek yorumlamaya çalışmıştır. Seanslarda Beril M.'nin içsel temsillerinin birbirlerine zıt ikilileri içerdiği görülmüştür ve danışanın bölme savunma mekanizması ilişkide ortaya çıktıkça, şimdi- veburada yaşanan duygusal durumun doğası çerçevesinde yorumlanmıştır. Kernberg (1975), kuramında da bahsettiği gibi, ikililer arasındaki bu ayırım, danışanın ikilileri birbirinden koruma amacına hizmet etmektedir. Bu bölmenin sevgi ile dolu olan ikiliyi nefret ile dolu olan diğer ikiliden koruma görevi üstlendiği varsayılmıştır. Seanslarda, nefret ile dolu olan ikilinin bilinç seviyesine daha yakın olduğu gözlemlenmiştir. Terapi süreci ilerledikçe, terapist Beril M.'nin daha gizli ve kırılgan olan sevilme ve önemsenme arzusunun farkına varmaya başlamıştır. Bilinç seviyesinde olan nefreti daha fazla yorumlayarak danışanın, nefretini savunma amacı ile kullandığının farkına varmasını sağlamaya çalışılmıştır. Bu süreçte danışanın aile bireylerine yazdığı mektuplardan bazı kısımlar şöyledir:

“Anneme... Çok kırgınlığım var sana anne. En büyük kırgınlığım, hep ablama karşı ezdirdin beni, hep ikinci plana ittin. Neden? (...) Keşke biraz daha ayaklarının üzerinde durabilseydin, bu kadar pasif olmasaydın. Tavrını koymayı bilseydin keşke. Keşke o küçücük yaşta bile seni savunmaya çalışmasaydım. Keşke anne!!!”.

"Babama... Hayatım hep senin ablama ve anneme kızıp sinirlenmelerini izlemekle geçti. Bana kızma diye de aslında hep sen ne istersen onu yapmaya çalıştım. (...) Anneme yeri geldi vurdun ve sen ona her vurduğunda ben de sana vurmak istiyordum ama yaşım küçük olduğundan hep annemin yanında sessizce durup üzülüyordum. Küçük olmak dünyanın en kötü duygusu oluyordu o anda. Ama içimden de hep ben büyüyünce bunların hesabını vereceksin baba diyordum." 
“Ablama... Hayatın hep beni itelemekle, küçük düşürmeye çalışmakla ve kıskanmakla geçti. (...) Ben hep seni sevmeye çalışırken sen beni hiçbir zaman sevmedin. (...) Seninki normal bir kardeş kıskançlığ1 değildi bence, sen resmen benden nefret ediyordun."

Beril M.’nin aile yaşantısına bakıldığı zaman, özellikle annesine karşı hissettiği öfkeyi, bilinç seviyesinde ablasına yönelttiği görülmektedir. Bu durum seanslarda, annesine karşı hissettiği sevgiyi, öfkesinden koruma görevi üstlendiği şeklinde yorumlanmıştır.

Genel olarak terapi sürecine bakıldığı zaman, netleştirme (clarification) ile danışanın duygu, düşünce ve davranışları üzerinden terapist, danışan ile iletişime geçmeye çalışmıştır. Bunun yanı sıra netleştirme ile terapist danışanın kendi duygu ve düşünceleri hakkında içgörü sahibi olup olmadığını sorgulayabilmiştir. Danışan ile kendi duygu, düşünce ve davranışları hakkında konuşarak iletişim gücü artırıldıktan sonra yüzleştirme (confrontation) yapılmaya başlanmıştır. Yüzleştirme, seans sırasında ortaya çıkan danışanın diline de yansıyan zıt ikililer arasındaki ilişkiyi danışana göstermeye çalışarak yapılmaya çalışılmıştır. Şimdi ve burada yorumlaması (interpretation) ile danışanın seans sırasında terapist ile olan ilişkisinde ortaya çıkan aktarımı sorgulanmıştır. Örneğin, danışan eleştirildiğini düşündüğü anda seanslarda öfkelenmektedir ve yansıtmalı özdeşim savunmasını kullanarak kendi öfkesini terapiste yansıtarak kendindeki 'kötü’ parçanın terapistte olduğunu hissetmektedir. Ancak danışan kullandığı bu savunmaya rağmen, öfkeli olmaya devam etmektedir. Bunun altında da danışanın bu özellikleri dışsal tehdit olarak algıladığı, bu dışsal tehditten korunmak için de inkar savunmasını kullandığı gözlemlenmiştir. Terapistin bu tür durumlarda danışana karşı aktarımı güçlü ve zorlayıcı olmaktadır. Terapi sürecinde terapistin karşı aktarımının zıt kutuplara ayrıldığı görülmektedir. Danışan zaman zaman sevgiye ihtiyaç duyan zayıf bir birey olarak görülmekte ve kendisine aşırı ilgi gösterilmektedir. Zaman zaman ise danışan manipülatif bir birey olarak görülmektedir ve karşı aktarım daha zorlayıcı olmaktadır.

Danışanın terapiye başladığından beri kendilik algısını kendisini daha az suçlayarak daha olumlu değerlendirmeye ve daha bütünleşmiş öteki algısına sahip olmaya başladığı gözlemlenmiştir. Ayrıca, başkalarını çelişkilerine rağmen sevme kapasitesiyle ilgili farkındalığının geliştiği görülmüştür. Bu gelişmeler danışanın diline de yansıyarak kendisini ve başkalarını tanımlarken 'kötü insan' ve 'iyi insan' ayrımlarını daha az kullandığı gözlemlenmiştir. Buna ek olarak, danışanın duygularını, özellikle öfkesini regüle etmede ilk seanslara göre daha az zorlandığı ancak tam bir bütünleşmiş kendilik ve öteki algısına henüz sahip olmadığı için zorluk yaşamaya devam ettiği görülmektedir.

\section{Sonuç}

Borderline kişilik örgütlenmesi, tutarsız ve çelişkili benlik ve öteki algısının yer aldığı, çoğunlukla bölme gibi ilkel savunmaların kullanıldığı ve gerçeği değerlendirme yetisinde eksikliklerin olduğu güçsüz benlik ile karakterize olan kişilik yapısı düzeyidir. Tutarsız ve çelişkili benlik ve öteki algısı, kişinin bebeklik döneminden itibaren geliştirdiği kendiliğini ve ötekini 'iyi' ya da 'kötü' şeklinde böldüğü savunma mekanizmasından kaynaklanmaktadır. Bölme mekanizması, nesne ilişkileri teorisine göre 3 yaş öncesi dönemde bebeğin birincil nesne, anne ile kurduğu ilişkiye dayanmaktadır. Bu nedenle, psikoterapi sürecinde temel olarak borderline kişiliğe sahip danışanın terapi sürecini domine eden nesne ilişkilerinin ortaya çıkarılması hedeflenmiştir ve 'iyi' veya 'kötü’ kutuplaşmasının çözülmesinin danışan ile kurulan terapötik ilişkiden yararlanması amaçlanmıştır. Beril $\mathrm{M}$. vakasında da görüldüğü gibi bu şekilde danışanın nesne ilişkilerinde tatmin edilmemiş ihtiyaçlarının farkındalığı kazandırılıp üzerinde çalışılarak bütünleşmiş kendilik ve öteki algısı geliştirilmeye başlanmış ve bu şekilde danışan kendisini ve ötekini tüm çelişkilerine rağmen sevebilme kapasitesini kazanmasının yolu açılmıştır. İnsanın karmaşık doğası göz önüne alındığında, 
Beril M.'nin öfkesini regüle etmede daha az zorlanmaya ve hayatındaki anlamsızlık ve boşluk hislerinin içsel motivasyon kaynaklarını bulmaya başladığı görülmüştür.

Son söz olarak Guntrip'in (2001) dediği gibi 'İnsan hayatının önemi nesne ilişkilerinde yatmaktadır ve nesne ilişkileri olmadan, ego kendisini geliştiremeyeceği için; sadece bu açıdan hayatımızın bir anlamı olduğu söylenebilir." (s. 19). 


\section{Kaynaklar}

Ainsworth, M. D. S. (1969). Object relations, dependency, and attachment: A theoretical review of the infant- mother relationship. Child Development, 40, $969-1025$.

American Psychiatric Association. (2013). Diagnostic and statistical manual of mental disorders (5th ed.). Arlington, VA: American Psychiatric Publishing.

Blom, I. ve Bergman, A. (2013). Observing development: A comparative view of attachment theory and seperation-individuation theory. J. E. Bettmann ve D. Demetri Friedman (Ed.). Attachment-based clinical work with children and adolescents (s. 9 - 43). New York: Springer.

Clarkin, J. F., Yeomans, F. E. ve Kernberg, O. F. (2006). Psychotherapy for borderline personality: Focusing on object relations. London: American Psychiatric Publishing.

Freud, S. (1905). On sexuality: Three essays on the theory of sexuality (J. Strachey, Çev.). Harmondsworth: Penguin Books. (1977).

Freud, S. (1914/1991). On narcissism: An introduction. J. Sandler, E. Person ve P. Fonagy (Ed.). Freud's "On narcissism: An introduction". New Haven: Yale University Press.

Freud, S. (1917). Yas ve Melankoli (A. Emirsoy, Çev.). İstanbul: Telos Yayıncılık. (2014).

Gabbard, G. O. (1994). Psychodynamic psychiatry in clinical practice: The DSM-IV edition. Washington, D.C.: American Psychiatric Press.

Göka, E., Yüksel, F. V. ve Göral, F. S. (2006). Projective identification in human relations. Türk Psikiyatri Dergisi, 17, $1-9$.

Guntrip, H. (2001). Schizoid phenomena, object-relations and the self. London: Karnac Books.

Jacobson, E. (1964). The self and the object world. New York: International Universities Press.

Kaslow, F. W. ve Magnavita, J. J. (2002). Comprehensive handbook of psychotherapy: Psychodynamic/ Object relations (Vol.1). New York: John Wiley \& Sons.

Kernberg, O. F. (1975). Borderline conditions and pathological narcissism. New York: Jason Aronson.

Kernberg, O. F. (1980). Internal world and external reality: Object relations theory applied. New York: Jason Aronson.

Klein, M. (1975). Envy and gratitude and other works 1946 - 1963. New York: Free Press. (1984).

Levy, K. N., Meehan, K. B., Kelly, K. M., Reynoso, J. S., Weber, M., Clarkin C. F. ve Kernberg, O. F.

(2003). Change in attachment patterns and reflective function in a randomized control trial of transferencefocused psychotherapy for borderline personality disorder. Journal of Consulting and Clinical Psychology, 74, 1027 - 1040.

Mahler, M. S., Pine, F. ve Bergman, A. (1975). The psychological birth of the human infant: Symbiosis and individuation. New York: Basic Books.

McWilliams, N. (2013). Psikanalitik tanı: Klinik süreç içinde kişilik yapısını anlamak. İstanbul: Bilgi Üniversitesi Yayınlar1.

Millon, T., Grossman, S., Millon, C., Meagher, S. ve Ramnath, R. (2004). Personality disorders in modern life. New Jersey: John Wiley \& Sons.

Mitchell, S. A. ve Black, M. J. (2012). Freud ve sonrast: Modern psikanalitik düşüncenin tarihi. İstanbul: Bilgi Üniversitesi Yayınları.

Yeomans, F. E. ve Levy, K. N. (2002). An object relations perspective on borderline personality. Acta Neuropsychiatrica, 14, $76-80$. 


\section{Summary \\ Overview of Borderline Personality Organization through the Framework of Object Relations Theory: Interpretation of Psychotherapy Process through Case Example}

Borderline personality organization is defined as identity dissolution (inconsistent and contradictory sense of self and other), the use of primary defenses (mostly splitting and projective identification), and failures in reality testing, all characterized by weak self. Beril M. is a 32 years old single working woman. Based on her application reasons and complaints occurring as agenda in the psychotherapy process, the therapist asserted that she has a borderline personality organization in line with the description. One of the primary theories formulating borderline personality organization is the object relations theory. Object relations theory has been seen as the progression of psychoanalytic theory. Object relations theory focuses on the relation between the infant and the primary object, the mother during 0 and 2 ages. At this stage, the infant has many satisfying and frustrating experiences in the relation with the caregiver. It causes the infant to develop defense mechanism that splits itself and the other as 'good' and 'bad'. Therefore, it is basically aimed to reveal the borderline patient's object relations dominating the therapy process. In addition it aims the resolution of 'good' and 'bad' split to benefit from the psychotherapeutic relation between the patient and the therapist. In this article, the psychotherapy process with Beril M. case is interpreted through borderline personality organization from the framework of object relations theory.

Keywords: object relations, borderline organization, Otto Kernberg 